\title{
CONCEPTUAL ANALYSIS AND THE VIRTUES AND VICES OF PROFESSOR WESTEN'S LINGUISTICS
}

\author{
TIMOTHY P. TERRELL*
}

Traditionally, or perhaps merely habitually, legal issues have been organized around major themes or concepts, such as "negligence," "contract," "liberty," and so on. The study of these various legal compartments-their present detail, their origins and development, and their normative foundations-I have as a matter of convenience labeled "conceptual analysis." Conceptual analysis is not, however, in the mainstream of contemporary legal scholarship. Despite remarkable diversity in both content and style, one recurring theme in current academic work is the notion that language and linguistic categories have little application to the resolution of legal controversies. According to conventional wisdom, words in and of themselves are too flexible and superficial to affect directly the deeper "policy" concerns that are truly at stake. ${ }^{2}$ Conceptual analysis, in contrast, takes legal language seriously, examining the complex relationships among words, reasoming, rhetoric, and ultimately, pohicy. In essence, it is concerned more with identifying the structure of legal questions than with finding discrete legal answers. It

* Professor of Law, Emory University School of Law. B.A., 1971, Maryland; J.D. 1974, Yale Law School; Dipl. in Law, 1980, Oxford Univ., Eng.

1. For my own exercises within this category, see infra notes 8,11. For a general diseussion of "conceptual studies and exercises," see Summers, Legal Philosophy Today-An Introduction, in EsSAys in Legal Philosophy 1 (R. Summers ed. 1968).

2. Nearly all modern analyses of words and phrases in the Constitution are examples of this approach. For a useful summary of some of the competing contemporary themes in this area, see Saphire, Constitutional Theory in Perspective: A Response to Professor Van Alstyne, 78 Nw. U.L. REV. 1435 (1984).

Of course, language may be "superficial" in the sense that it does not necessarily control the outcome of a controversy. Nevertheless, language may play a number of different roles that will make it "important." Thus, language may be characterized as indefinite, but it is not generally regarded as irrelevant. Indeed, language may be an active contributor (or obstacle) in social processes. Scholars within the Critical Legal Studies movement have been the most consistent in noting the substantive harm that traditional linguistic categories and forms can impose. Language, they argue, reflects and guides contemporary patterns of moral thought and, thus, in the context of law it may assist in perpetuating illegitimate forms of domination and alienation. Language ceases to be a neutral medium of communicative exchange. For an extensive discussion of this and related points, see Heller, Structuralism and Critique, 36 STAN. L. REv. 127, 133-55 (1984). Other recent sources include J. WhITE, WHEN WORDS LOSE THEIR MEANING: Constitutions AND RECONstitutions of Language, Character, ANd Community (1984); Ball, When Words Lose Their Meaning, 96 ETHICS 620 (1984). 
suggests, however, that legal answers will never be adequate until the questions are better understood.

Professor Peter Westen has over the past few years paid much attention to the structure of legal questions, specifically questions involving the concept of "equality." 3 However, in his inost recent article, "Freedom" and "Coercion"-Virtue Words and Vice Words, ${ }^{4}$ Professor Westen broadened his analysis considerably to examine inore general issues of legal and moral linguistics. 5 Although Professor Westen and I share several important conclusions about tlie nature and importance of language in legal contexts, I am compelled to take exception to certain points in Virtue Words and Vice Words. The purpose of this article is to identify tliose points, and througli tliem to discuss fundamental issues concerning the nature of legal and moral discourse.

I must einpliasize tliat despite iny criticisins of his linguistic analysis, tlie points on whicli I agree witl Professor Westen are inore significant tlian those on which I disagree. We are in accord, for example, on the most basic issue of all: tlie importance and usefulness of conceptual analysis. Many legal scholars would deny even this point, suggesting tliat the indeterminacy of legal rules is in part due to the indeterminacy of language. ${ }^{6}$ Although tlis insight is not new, ${ }^{7}$ recent scliolarship has gone further and virtually disimissed the prospect of learning anytling of

3. See Westen, The Concept of Equal Opportunity, 95 ETHICs 837 (1985); Westen, The Meaning of Equality in Law, Science, Math, and Morals: A Reply, 81 MicH. L. REv. 604 (1983) [hereinafter Westen, Meaning of Equality]; Westen, To Lure the Tarantula From Its Hole: A Response, 83 Colum. L. Rev. 1186 (1982); Westen, On "Confusing Ideas": A Reply, 91 Yal.e L.J. 1153 (1982); Westen, The Enipty Idea of Equality, 95 HARv. L. REv. 537 (1982) [hereinafter Westen, Equality]. Most of these writings were prompted by criticism of his thesis by other scholars. See Chemerinksy, In Defense of Equality: A Reply to Professor Westen, 81 MicH. L. REV. 575 (1983); D'Amato, Is Equality A Totally Empty Idea?, 81 MrCH. L. REv. 600 (1983); Greenawalt, How Empty Is the Idea of Equality?, 83 Colum. L. Rev. 1167 (1983); Karst, Why Equality Matters, 17 GA. L. REv. 245 (1983).

4. Westen, "Freedom" and "Coercion"-Virtue Words and Vice Words, 1985 DUKE L.J. 541.

5. I use the term "linguistics" rather loosely here and throughout the article to refer generally to the range of subjects sometimes categorized under headings such as philology, morphology, linguistic philosophy, and philosophy of language. For a summary discussion of the distinction between linguistic philosophy and the philosophy of language, see B. MAGEE, MEN OF IDEAS 182-200 (1978). Much has been written on the philosophy of language. Some of the more basic or wellknown works are: N. Chomsky, Reflections on Language (1975); D. CoOper, Philosophy and the Nature of Language (1973); T. Hacking, Why Does Language Matter to PhILoSOPHY? (1975); R. HARE, The LANGUAGE OF MORAls (1952); W. Quine, Word AND OBJECT (1960); J. Searle, Speech Acts (1969); The Philosophy of Language (J. Searle ed. 1971); L. Wittgenstein, Philosophical Investigations (G. Anscombe trans. 3d ed. 1971).

6. See Boyle, The Politics of Reason: Critical Legal Theory and Local Social Thought, 133 U. PA. L. REV. 685, 708-21 (1985).

7. See H. HaRt, The CONCEPT OF LAw 124 (1961). 
value by studying the background nature of basic legal concepts. ${ }^{8}$

This attitude, however, misses a crucial point. While vagueness and flexibility are certainly inherent features of language, "indeterminacy" has been confused with the related but quite distinct idea of "unstructured." Even though relevant textual authority may not dictate a particular resolution to a complex legal problem, the problem itself will nevertheless have an identifiable structure. Conceptual analysis is anchored in the behief that this structure results im part from the language used to express the problein, and that this language is subject to a corresponding internal organization.9 Although particular words may not have single, completely uncontroversial meanings, linguistic variability will follow certain patterns that can be discovered through conceptual legal analysis. The primary function of this analysis is to make legal debate more focused and deliberate, and perhaps more honest.

Professor Westen's work, ${ }^{10}$ like my own, ${ }^{11}$ has consistently sought to convey this message. While I have analyzed concepts such as "property" and "liberty," he has used "equality" as his test case, criticizing the superficiality of the legal rhetoric that employs the term. He has concluded that the concept of equality, properly examined and understood, is descriptively "empty," possessing only the varying normative content that particular individuals choose to give it. ${ }^{12}$ Although I disagree in part with this conclusion ${ }^{13}$ (and indeed Professor Westen seems to have modified his views on this point ${ }^{14}$ ), I am nevertheless in complete agreement with the importance he attaches to the linguistic analytic exercise. Thus, my criticisms of Professor Westen's approach, as fundainental as I beheve them to be, are more like a squabble between kinfolk than a battle between warring tribes.

8. This has been the consistent picture presented by eourts and commentators with regard to the basic concepts of "property," "liberty," and "due process" that I have examined specifically. See Terrell \& Smith, Publicity, Liberty, and Intellectual Property: A Conceptual and Economic Analysis of the Inheritability Issue, 34 EMORY L.J. 1 (1985); Terrell, Liberty: The Concept and Its Constitutional Context, 1 Notre Dame J.L. ETHICs \& PuB. PoL'Y 545 (1985) [hereinafter Terrell, Liberty]; Terrell, "Property," "Due Process," and the Distinction Between Definition and Theory in Legal Analysis, 70 GEo. L.J. 861 (1982) [hereinafter Terrell, "Property," "Due Process"].

9. This organization or structure involves not only the (relatively) independent functions performed by descriptive and normative mental activities that are the basic subject of this comment, but also the nature of the definitional exercise by itself. See infra note 20.

10. See supra note 3 .

11. In addition to the articles listed in note 8, supra, see Terrell, Flatlaw: An Essay on the Dimensions of Legal Reasoning and the Development of Fundamental Normative Principles, 72 CAL. L. REV. 288 (1984).

12. Westen, Equality, supra note 3, at 547-48.

13. See Terrell, Liberty, supra note 8 , at 548 n. 10 .

14. See infra notes $79-80$ and accompanying text. 
Even that squabble is a narrow one, for we also agree on certain important techriques within conceptual analysis. We have both argued that two rather distinct elements-one based in objective ${ }^{15}$ data, the other in subjective normative assessment-generate the ineaning or substance of a term. He has labeled these elements description and prescription; ${ }^{16}$ I have referred to thein as definition and theory. ${ }^{17}$ Although I will later note some fundamental differences between our understandings of these elements, ${ }^{18}$ we share the basic "fact-value" dichotomy that serves as the foundation of this approach. Moreover, in Virtue Words and Vice Words, Professor Westen has for the first time used the descriptive technique of identifying the "core" constitutive elements of the concept under investigation, ${ }^{19}$ a techinque that has played a particularly inportant role in iny previous work. ${ }^{20}$ In spite of this agreement between us,

15. "Objective" is of course a very dangerous word. Much philosophic effort has been spent disproving that any approach can be truly objective. See generally THE PoLITICS OF INTERPRETATION (W. Mitchell ed. 1983). For present purposes I will bypass most of that debate and assume that enough of a distinction exists between objectivity and subjectivity to make the term "objective" meaningful. In other words, I shall assume that individual perceptions of events or objects have enough in common, and are not so tainted with preexisting bias or distortion, that "facts" can be denominated and used as one basis for communication. See infra notes 81-87 and accompanying text.

16. See Westen, supra note 4, at 589-91; Westen, Meaning of Equality, supra note 3, at 607.

17. See, e.g., Terrell, "Property," "Due Process," supra note 8, at 862.

18. See infra Part IIA.

19. See Westen, supra note 4 , at $549,559-69$.

20. See Terrell, Liberty, supra note 8, at 554; Terrell, supra note 11, at 311-16; Terrell, "Property," "Due Process," supra note 8, at 865-74.

Differences between my approach to language and that of Westen exist here as well, though I am not certain of the degree to which we differ. In a footnote, Westen apparently attempts to forestall those who would criticize him for linguistic formalism in his use of core elements to establish the meaning of concepts. He explains:

I do not mean to say that all statements of "freedom" must have a common meaning merely because they all use the same word. I recognize the fallacy of assuming that all uses of a given term are necessarily predicated on the presence of "common qualities" among the things to which they refer.... Rather, I believe that all statements of "freedom" have a core meaning, not because they must, but because ordinary usage shows that they do.

Westen, supra note 4, at $549 \mathrm{n} .31$. I believe Westen is partially correct on this point, but the difference between our depictions of the role of the core meaning of a term is significant. In my opinion, Westen seems to conflate the separate ideas of "core" meaning and "common" or shared meaning. Although I would agree that "common" meaning is not a necessary characteristic for the use of a term with open texture, a "core" meaning is a necessary predicate for the labeling of a conceptual entity.

I have in the past referred to core meaning as "focal" meaning, a term borrowed from John Finnis. See J. Finnis, Natural LaW and Natural Rights 6, 9-11 (1981). Perhaps the difference in labeling helps to explain the subtle distinction between this central conception of an entity and the more general idea of common elements constituting that entity. The term "focal" captures the function of this exercise in the context of set theory. The use of any label denotes an attempt to differentiate something from something else. This differentiation suggests that the use of the label may be appropriate or inappropriate in particular instances. The occasions on which the term is appropriately used can be grouped into a set. The purpose of any definition is to identify the ele- 
however, this article will demonstrate that very different linguistic conclusions can be generated from rather similar starting points.

Those portions of Professor Westen's article that are directly relevant to the general topic of conceptual analysis can be summarized in three interrelated stages. He argues, first, that a "virtue-vice" category of words exists; second, that this category can be identified by reference to two key linguistic characteristics; and third, that this category is worthy of study because the terms within it have "great rhetorical force." As to

ments according to which such a set is established. The traditional problem with definitional exercises, however, has been that the boundary or perimeter of these sets-the "line" of their separation from "mappropriate" uses of the term-is always hazy to some degree, suggesting that the sets themselves are unstructured collections of largely incommensurable, ad hoc, unfocused uses of the word. Ludwig Wittgenstein argued, for example, that the most organization one could expect from the elements constituting a concept was a certain "family" connection or resemblance linking one example with another, but with no particular characteristics necessarily being common to all of them. See L. Wittgenstein, supra note 5, at 2-41; see also Terrell, "Property," "Due Process," supra note 8 , at 867 n.21. This is what Professor Westen seems to have in mind when he denies the necessity for "common qualities."

The theory that terms have "focal" meaning, on the other hand, suggests that the sets representing the use of terms do have a structure and are linked more rigorously than the "family" connection suggested by Wittgenstein. The sets will not be a jumble of isolated instances, but rather hierarchically organized series. At the "center" will be the archetypical example of the use of the term-a use that everyone agrees captures all of the term's essential elements. As one or more of these elements is missing in uses of the label, the example moves away from the "focal" meaning and out toward the perimeter of the set. At some point, so many of the elements that characterize the term are absent that the nse of the label is perceived as being outside the boundary of the set; the use of the term is no longer appropriate. To understand where the boundary lies between appropriate and inappropriate uses of a term, reference must be had to the central or focal case. Thus, various peripheral uses of a complex term of several constitutive elements may indeed, as Professor Westen suggests, have nothing in common with each other. I would argue, however, that they nonetheless will always have some element in common with the focal meaning of the term. For example, a term might be characterized by four eleinents: A, B, C, and D. The simultaneous presence of all these elements would constitute the central or focal case. A peripheral use of the term might have elements $A$ and $B$, while another has only $C$ and $D$. Both might be considered legitimate uses of the label in question, but a sophisticated exercise is required to identify the nature of the relationship between the two uses of the term.

A "core" meaning for freedom, therefore, does not exist just by coincidence, as Professor Westen's footnote suggests, but because such a meaning is essential for the set to which the label "freedom" is applied. And that "core" or "focus" will exist even though various examples of how the term is used may have no elements "in common" with each other. The commonality always refers to the core, not to particular uses of a term on the periphery of legitimacy.

This linguistic exercise is not of critical importance to Westen's analysis of freedom, however, because he concludes that each use of the term "freedom" is characterized essentially by the presence of all three elements that constitute the core meaning of the term: (1) an agent (2) unconstrained (3) to achieve some goal. Westen, supra note 4, at 551-55, 590. The "freedom" set will then be structured according to the degree to which each of these elements is specified. As Professor Westen puts it: "There is an inverse relationship between the degree to which the terms of a concept are specified and the extent to which it is open-textured or 'protean' . . . Id. at 590. Thus, in contrast to my hypothetical example above, no uses of the term "freedom" will exist under Professor Westen's analysis that have only some of the characteristics that constitute the core meaning; instead, all uses of the term freedom will have all three of his basic elements in common. 
Professor Westen's first step, the existence of a virtue-vice category is based on the notion that concepts are the product of some function of description and prescription. ${ }^{21}$ In Virtue Words and Vice Words, Professor Westen focuses on those uses of language in which a normative message is of particular importance-circumstances mvolving "conceptions of good and evil."22 $\mathrm{He}$ concludes that this kind of moral discourse will often involve a distmct linguistic category-one that contains what he calls "virtue words" and "vice words."23

Professor Westen then argues that virtue words and vice words possess two characteristic features. First, although these terms retain their own special identity, they nevertheless can and do vary in actual usage across a range of particular and even contradictory meanings. ${ }^{24}$ Professor Westen uses the familiar descriptive phrase of "open texture" to suininarize this attribute. ${ }^{25}$ The second feature of virtue words and vice words is that they "tend to convey normative judgments without being defined as expressing normative judgments." 26 Thus, virtue words and vice words are neither entirely descriptive nor entirely normative in content.

To illustrate the category of virtue words and vice words, Professor Westen focuses on the terms "freedom"27 and "coercion."28 An important element in his development of this category is a contrast he attempts to establish between these words and two other categories of terms. $\mathrm{He}$ describes the term "federal," for example, as a "descriptive, normatively neutral" term and "justice" and "duress" as terms that are normative by definition. 29

Finally, Professor Westen asserts that the terms with which he is primarily concerned demand special attention because the features of open texture and nonlexical normativity "combine to give virtue words and vice words great rhetorical force."30 As he summarizes this point:

Because they are protean, they are versatile. They are vehicles through which people can express their most deeply-held moral beliefs, without the necessity of making those beliefs morally consistent. Moreover, because virtue words and vice words tend to be normative, they tend to

21. See Westen, supra note 4, at 554 (noting the distinction between "descriptive freedoms and prescriptive freedoms").

22. Id. at 542 .

23. Id.

24. Id. at 543-44.

25. Id.

26. Id. at 544 .

27. Id. at 546-47, 549-58.

28. Id. at 547-48, 558-89.

29. Id. at 544-45.

30. Id. at 546. 
persuade. They tend to tilt or point moral discourse in the direction the speaker wishes it to go, whether the speaker happens to be endorsing a particular position or condemning it. Finally, because they are nonlexically normative, they tend to persuade without being completely conclusory. They point moral discourse in the direction the speaker wishes it to go without enabling his opponent to say that he has simply defined away the issue. ${ }^{31}$

My criticism of Professor Westen's reasoning focuses on the second of his three analytic stages-the linguistic characteristics that are supposed to set his "virtue-vice" category off from other words. I will challenge his depiction of both "open texture" and "nonlexical normativity," and the relationship between thein. This will in turn raise serious questions about his first and third stages: the virtue-vice category itself, I will argue, does not exist as he has attempted to develop it, nor do the words purportedly within it appear to have the rhetorical force he has ascribed to them.

These points are developed im various ways in all the sections of this article; criticizing the central step in Professor Westen's linguistic analysis inevitably challenges the others. Thus, the organization of my remarks revolves around different matters. Part I concentrates on Professor Westen's own version of the virtue-vice category. In the first section of Part I, I dispute the linguistic uniqueness and importance of that category; in the second section, I question the adequacy of Professor Westen's separation within this category of virtue words from vice words. My misgivings about the linguistic analysis in Virtue Words and Vice Words then prompt me to investigate at a inore fundamental level the description-prescription dichotomy that generated this troublesome virtue-vice category im the first place. I shall argue in Part II that the generative elements of meaning in legal and moral concepts are more complex than either Professor Westen or I have previously suggested.

I have chosen not to discuss in this article the inany differences between the analytic conclusions Professor Westen and I have reached concerning the particular concepts of freedom and liberty. ${ }^{32}$ Although those

31. Id.

32. For example, Professor Westen identifies three elements as constituting the core meaning of "freedom." See supra note 20. By contrast, I have argued that the focal meaning of "liberty" has nine elements. Terrell, Liberty, supra note 8, at 554. Westen also differentiates freedom from liberty; he considers liberty a subset of freedom. According to Westen, liberty refers "to a relationship in which a particular class of agents (i.e., purposeful agents) are unhindered by a particular class of constraints (i.e., human constraints) to pursue their goals." Westen, supra note 4, at 591. Although I believe there might be possible distinctions between the two terms, see Terrell, Liberty, supra note 8 , at $549 \mathrm{n} .11$, the differences are too narrow and strained to make the distinction between the terms meaningful. I am not convinced by Westen's limitation of "liberty" to human contexts, and the corresponding expansion of only freedom to nonhuman contexts such as, to use his example, "The river is free from pollution." Westen, supra note 4, at 591. I would argue that our use of "free" 
disagreements are interesting and thought-provoking in their own right, I consider them secondary to the more general linguistic issues raised by his article.

\section{The Inadequacies of the Virtue-Vice Category}

\section{A. The Nature of Virtue and Vice Words.}

The primary difficulty I have with Professor Westen's development of the "virtue-vice" category is his assumption that two fundamental characteristics distinguish the words within this category from other words. In fact, these characteristics-open texture and nonlexical normativity-do not, either singly or in combination, 'generate the result he seeks. Open texture is a feature of nearly all words, but particularly those words used in legal and philosophical discourse. Similarly, nonlexical normativity fails to tell us anything useful or meaningful im our effort to understand these types of terms.

I am not certain whether Professor Westen considers open texture to be a feature umique to virtue words and vice words, or a feature of all language that just happens to be particularly important with respect to these terms. Early in Virtue Words and Vice Words he describes both open texture and nonlexical normativity as "distmetive"33 characteristics, suggesting that each feature is uniquely attributable to virtue words and vice words. As his argument develops, however, Professor Westen suggests that the combination of open texture and nonlexical normativity is actually the key to this linguistic category. ${ }^{34}$ Surely he intends the latter, because any attempt to hinit open texture to the category of virtue and vice words is impossible (as he himself seems to acknowledge in an early footnote ${ }^{35}$ ). I do not think he ineans to say that terms such as "federal," "justice," and "duress"-terms he places outside the virtue and vice category-have a "closed," determinate character. The meanings of these terms are neither descriptively fixed nor are their prescriptive backgrounds himited to consistent norms or values. Open texture in and of itself is therefore not important to Professor Westen; its importance arises only when it is considered in combination with the second

rather than "liberated" in this example either reflects an unconscious decision to use one syllable rather than four, or that the term "liberated" has an added connotation of physical activity (whether human or not) that is not present in "free" or "freed." Note, for example, that those most human of actions-speech and religious worship-are referred to in the Constitution as "freedoms," not "liberties." See U.S. CoNST. amend. I.

33. Westen, supra note 4 , at 542-44.

34. Id. at 589.

35. Id. at 543 n.4 ("open texture" refers "to an irreducible feature of all empirical descriptions") (citing Waismann, Verifiability, 19 Proc. ArISTOTELIAN Soc'y 119, 123 (Supp. Vol. 1945)). 
feature, nonlexical normativity. The significance of Professor Westen's linguistic analysis will consequently depend on the nature of that combination and the substance conveyed by the concept of nonlexical normativity.

An examination of nonlexical normativity, lowever, reveals that it, too, fails to provide meaningful guidance concerning the content of the "virtue-vice" category. One initial difficulty is that Westen's description of this essential feature seems to vary within the article, thereby suggesting different possible classification schemes. Initially he describes nonlexical normativity as normative ambiguity ${ }^{36}$-that is, virtue words and vice words have some independent content that connotes more than the simple normative judgments of "good" or "bad." Consequently, these terms will merely have normative tendencies rather than predetermined normative content. In the conclusion to the article, lowever, Professor Westen describes nonlexical normativity more broadly as "the feature of having descriptive as well as prescriptive meanings." 37 These two notions of nonlexical normativity each imply a distinct categorization scheme, and each is defective for different reasons.

Assume first that the key feature Professor Westen has in mind for virtue words and vice words is normative ambignity. This characterization imphes that terms will apparently fall into one of three broad categories: at one extrenie, the normatively neutral (such as "federal"); at the other extreme, the inevitably normative (sucl as "justice" and "duress"); and in the middle, the ambiguously normative (virtue words and vice words). Assuming this typology is accurate, I fail to see its significance. Professor Westen asserts at the beginning of his article that the normative ambiguity of virtue words and vice words contributes to their "great rletorical force" 38 because this ambiguity puts one's opponent on the defensive without simply begging the normative question involved. ${ }^{39}$ Yet if I correctly understand "rhetorical" to inean "persuasive," 40 the normative ambiguity of one's message would seem to reduce, rather than enhance, its force. ${ }^{41}$ Moreover, Professor Westen asserts in the conclu-

36. Id. at 545 .

37. Id. at 590.

38. Id. at 546.

39. Id. Professor Westen does not substantiate this claim. Moreover, in controversies about the meaning of freedom in phrases such as "the free exercise of religion," use of the term does tend to beg the normative question involved. See Van Alstyne, Trends in the Supreme Court: Mr. Jefferson's Crumbling Wall-A Comment on Lynch v. Donnelly, 1984 DUkE L.J. 770, 780-81.

40. Professor Westen seems to equate rhetorical force with persuasiveness. See Westen, supra note 4 , at 593 .

41. An excellent discussion of the relationship between rhetoric and persuasion appears in McCloskey, The Rhetoric of Economics, 21 J. ECON. LITERATURE 481, $482-84$ (1983). 
sion to the article that rhetorical power is based not on the ability of these terms to contribute to the argument at hand, but on their ability to bypass it. ${ }^{42}$ Again, I do not see how this makes such words "persuasive." To whom? Some important psychological or epistemological principle remains unidentified here.

Perhaps I do not sufficiently understand what Westen means by "rhetorical" force. Perhaps his poimt is not that these virtue words and vice words are unusually persuasive, but instead that these terms appear with unusual frequency in rhetorical exchanges because of their open texture and underlymg ambiguous normative content. But if this is what he means, I do not think that he has actually proven this point or shown that it would have any particular linguistic siguificance.

Now assume instead that nonlexical normativity does not inean normative ambiguity, but refers to the interplay of the descriptive and normative elements that generate the ineanings of virtue words and vice words. Under this version, three categories of terms can also be inferred, but these categories are quite different: at one extreme, words with only descriptive content ("federal"); at the other extreme, words with only normative content ("justice" and "duress"); and im the middle, words with both descriptive and normative content (virtue and vice words). I disagree. These categories may, at most, be sections along a contmuuin - different in degree only, not in kind-because all terms that have any significance in legal or philosophical discussion will have both descriptive and normative elements jointly generating their substance..$^{43}$ Of course, one element may be more important than the other im particular instances, but both elements will nevertheless be necessary to some degree. The only exception to this proposition would be uses of language that are of no interest to this discussion. The terms Professor Westen uses as examples dernonstrate this proposition.

In what sense, for example, is the term "federal" solely descriptive? The only circumstance $m$ which I can envision this occurring is when the term is examined without reference to any context whatsoever-where no legal or political issue of any sort is mvolved or at stake, where the use of the term "federal" is effectively equivalent to the use of the term "blue." Thus, the term is not inherently solely descriptive; rather, it becomes so only because normative issues are contextually irrelevant. To understand its "meaning," no reference to underlying norms or values (ultimately, to senses of "goodness" or "badness") is necessary. But this situation can have no relationship to the "meaning" of "federal" in its

42. Westen, supra note 4 , at 593.

43. See Terrell, "Property," "Due Process," supra note 8, at 865-78. 
usual legal contexts. There, the substance of the term will inevitably involve some measure of normative reference. In any actual controversy concerning our federal system of government, some "theory" of federalism-some examination of the value-laden merits and demerits of this governmental structure-will inescapably be invoked by both sides to the controversy, as well as the decisioninaker, to complete the analytic process. ${ }^{44}$ Only then could we determine, for example, whether a system of conditional grants from a central authority to local political units is consistent with (i.e., would be a legitimate exercise of power in) a federal form of government. ${ }^{45}$

This inevitable normativity of all terms also has implications for the notion of "rhetorical force," so important to Westen's hinguistic analysis. Because the notion of "rhetorical force" can be significant only in the context of a controversy, a term like "federal," which will be infused with normative content in such a context, has rhetorical force even though it is outside the virtue-vice category. Professor Westen claims, however, that virtue words and vice words are distinctive because they possess "great rhetorical force." 46 The question, then, is whether "federal" has so much less rhetorical force than virtue words and vice words that it is analytically meanimgful to place it im a different linguistic category.

I see no clear answer here at all. The degree to which a term is persuasive will depend on the argument in which it is used and concernmg which it can be assessed. Rhetorical power, therefore, is obviously not only a context-specific continuum, but more importantly a function of the complex interplay of both descriptive and normative elements. Any distmctions between identifiable categories along this functional continuum wonld inevitably be fuzzy and far more difficult to identify than Professor Westen's analysis would suggest. Moreover, this continuum of rhetorical power may be generated by factors deeper than the description-prescription dichotomy upon which Professor Westen relies, a poimt I will develop to a limited extent later in this discussion. ${ }^{47}$

The confusion concerning the nature of this second feature of virtue and vice words (i.e., possession of descriptive and prescriptive elements) also plagues Westen's other category of terms-the one into which he places "justice" and "duress." Imitially, he observes that these terms are

44. See, e.g., Younger v. Harris, 401 U.S. 37, $44-45$ (1971) (discussing "Our Federalism").

45. See L. Tribe, American Constitutional Law 247-50 (1978) (discussing competing views of the Congressional spending power).

46. Westen, supra note 4 , at 546.

47. See infra Part IIB. 
inevitably normative-they always refer to "goodness" or "badness." 48 Since I have argued that all terms have a normative component, I do not disagree with this conclusion as such. On the other hand, I do not believe a distinct category of terms can be delineated on this basis. More importantly, however, Professor Westen later suggests that these terms are distinct froin virtue words and vice words because they are entirely normative 49 - they are someliow descriptively neutral or without descriptive content. Agam, I must disagree. Because I posit that the substance of all terms is at all times a function of both descriptive and normative elements, I must reject this category of "only normative" words just as I rejected the category of "only descriptive" words. And just as I have argued that words can be "only descriptive" when used in circumstances isolated from significant context, so too, words can be "only normative" in the absence of context. For example, the words "good" and "bad" seein to be candidates for the category of "only normative" terms since tliey seem to convey a normative judgment without reference to any underlying factual detail.50 But the moment they are placed in context"good book" or "bad grades"-a descriptive element is unavoidably added to the normative imquiry.

This conclusion also liolds true for Professor Westen's own examples of "justice" and "duress." The content of "justice" in a social context is a descriptive as well as a normative matter. An excellent illustration of an effort to elucidate the "core" or central descriptive elements of the concept of justice is that of H.L.A. Hart in The Concept of Law. ${ }^{51}$ Initially, Professor Hart ties the descriptive and normative elements of justice together by using a descriptive, "ordinary language" approacli to narrow the normative scope of tlie term: "[T] he point of moral criticism in terms of justice or injustice is usually different from, and more specific than, the other types of general moral criticism which are appropriate in this particular case and are expressed by words like 'wrong,' 'bad,' or 'wicked.' "52 He then identifies tlie central descriptive elements of justice, including primciples sucli as "treat like cases alike ...

48. Westen, supra note 4, at 544-45.

49. Id. at 591.

50. Even this point need not be conceded, however, for terms that seem to be wholly normative are nevertheless a part of our language, and must take on their meanings in that context. Thus, even a term like "good" is understood to have the background descriptive content of positiveness rather than negativeness. See generally R. HARE, The LANGUAGE of MORAls 79-150 (1952). This does not mean, of course, that language cannot be turned on its head for special effect or purpose, such as in the colloquial use of "bad" to convey positiveness. The preexisting content of the term, however, is the feature that permits special usage.

51. H. HART, supra note 7, at 151-80.

52. Id. at 154. 
and . . different cases differently," 53 proportionality, ${ }^{54}$ impartiality, ${ }^{55}$ and objectivity. ${ }^{56}$ Descriptive criteria are also involved when he distinguishes between "distributive" and "compensatory" senses of justice. 57 Another example of the importance of the descriptive meaning of justice is Professor Guido Calabresi's effort in a recent article ${ }^{58}$ to articulate the relationship between justice and economic efficiency. He concludes at one point: "I have always believed that efficiency and distributional language does not translate directly into justice language; that there are components of the just society that could only be encompassed in the terms efficiency and distribution if these terms were given a ineaning far different from their ordmary ones." 59

These uses of the term "justice" illustrate that descriptive detail is necessary for all terms, not simply to develop the "full" ineaning of the term in the manner expected of scholars, but also to develop any meaning, even for the purpose of obfuscation or some other rhetorical goal. The reason is, quite simply, that the absence of any definitional structure would make the use of "normative" terms completely incoinmensurable from one speaker (with his or her particular normative agenda) to the next. ${ }^{60}$ The key element that leads speakers and their audiences to beheve that a debate on an issue has actually been jomed is this underlying descriptive essence that permits some (although perhaps quite limited, imperfect, and manipulable) linguistic comparability. ${ }^{61}$

I conclude, then, that Professor Westen's category of virtue words and vice words, to the extent it exists at all, at most contains terms that have a peculiarly heavy normative component. This component may

53. Id. at 155 .

54. Id.

55. Id. at 156.

56. Id.

57. Id. at $154-55,159-61$.

58. Calabresi, About Law and Economics: A Letter to Ronald Dworkin, 8 HofsTRA L. REv. 553 (1980).

59. Id. at 559. Calabresi's sense of "distribution" is of course very different from Hart's use of the term as a definitional component of justice.

60. I am not certain that I undertsand Professor Westen's message about these "normative" terms. With reference to his separation of description and prescription, he may be arguing that certain words that have both these elements (i.e., virtue words and vice words) have two separate and independent meanings, both somehow legitimate. Or he could be contending that description and prescription are independent elements that comprise a single legitimate "range" of meaning for these words. I believe only the latter position is viable. For a term to be used in discourse at allfor it to have any rhetorical value-that term cannot be used by two speakers who give it entirely separate meanings. For debate to oceur, some modicum of common ground will be necessary. Thus, the two speakers might emphasize separate elements or sources of meaning, but at some fundamental level they have to be considered to be talking about the same subject. Entirely independent mennings would not seem eapable of producing this result.

61. See supra note 20 (discussing the linguistic theory of "focal meaning"). 
regularly overwhelm the descriptive elements of the term in particular controversies or relegate those elements to a secondary status. Nevertheless, the distimction between this category and the categories into which he places "federal," "justice," and "duress" is extremely fuzzy and troublesome. If "rhetorical force" is defined, as Professor Westen suggests at the end of his article, as the capacity not to facilitate argument but to bypass it, ${ }^{62}$ then any term from any of these categories would potentially possess this characteristic simply by a speaker's selective emphasis of either the term's descriptive or normative elements, whichever will insulate it from the relevant detail of the argument at hand.

\section{B. The Distinction Between Virtue Words and Vice Words.}

The strongest and most interesting part of Professor Westen's article is his analysis of the concepts of "freedom"63 and "coercion."64 His consistent reference to the distinction between descriptive and prescriptive uses of these terms ${ }^{65}$ yields much of value; it helps structure our understanding of the ways in which these terms are used. Unfortunately, some of his conclusions concerning these terms are questionable simply because he links them to his troublesolne general limguistic category of virtue and vice words. For instance, the terms "freedom" and "coercion" are for him representative examples drawn from the two halves of the virtue-vice category, and they are intended to illustrate the distinction between a "virtue" word, on the one hand, and a "vice" word, on the other. I find this division within the category almost as troubling as the category itself.

The distinction is apparently based entirely on the normative eleinent inherent in each term, one positive and the other negative. Thus, virtue words, as Professor Westen puts it, convey botl1 "is and ought,"66 while vice words convey "is and ought not." 67 Yet this simple separation can be understood in two very different ways depending upon the nature of the virtue-vice category itself. First, Professor Westen could be understood as saying that all terms having both descriptive and prescriptive components will be either virtue words or vice words. Thus, the two sets-descriptive-prescriptive words and virtue-vice words-would be coextensive. Or, second, he could mean more simply that some words in the descriptive-prescriptive set have particularly "heavy" normative

\footnotetext{
62. Westen, supra note 4, at 593 .

63. Id. at 549-58.

64. Id. at 558-89.

65. See id. at 554-58, 575-89.

66. Id. at $555,558,591$.

67. Id. at 591 .
} 
components and consequently may be grouped naturally at the extremes of this category. Under this view, terms that quahify for the special "virtue" and "vice" labels would not be a distmct category, but rather subsets within the larger descriptive-prescriptive set.

I think either of these formulations is incorrect. If he means that the virtue-vice category and the descriptive-prescriptive set are coextensive, then into which camp, taking but one among countless examples, does the term "property" fall? Certainly that word has both descriptive and normative elements; $; 8$ consequently it must also be a virtue or a vice word. But which is it? For many people it will no doubt be a virtue word, but not for everyone, even within the single social context of the United States. 69 Thus, the labels "virtue" and "vice" cannot comfortably and ineaningfully exhaust the obviously larger descriptive-prescriptive category.

If, on the other hand, Professor Westen agrees with this conclusion and only means that virtue words and vice words occupy the extremes of the larger descriptive-prescriptive category, then the significance of his analysis is seriously dimimished. With reference to his guiding principles of description and prescription, I would state the point more simply: although all terms are comprised of both these elements, virtue words and vice words have the special characteristic of an unusually heavy emphasis on the normative aspect that generates their substance. In effect, we recognize in advance that the normative element in such terms is the dominant variable in a "meaning" function, and the descriptive element is subordimated.

Despite the intuitive appeal of this conclusion, I have nagging doubts about its accuracy if it is conjoined with Professor Westen's observation that the predominate normative component in virtue words and vice words is also tinged in advance with inherent positive or negative connotations. Rather than challenge this idea directly, however, I would suggest a supplemental linguistic hypothesis that Professor Westen himself notes, ${ }^{70}$ but does not develop. Perhaps the rhetorical power-or more accurately, the frequency of use in rhetorical exchange - of the words he has identified derives not simply from their preexisting, insufficiently anchored normativity, but moreover from their ability to slide back and forth between positive and negative normativity between moral approbation and moral condemnation, based on the speaker and the context. A good example is Professor Westen's vice

68. See Terrell, "Property," "Due Process," supra note 8, at 865-79.

69. The distinction between individual opinions and "social" or group-referenced opinions is itself an important problem. See infra Part IIB.

70. See Westen, supra note 4 , at 593 . 
word "coercion," which he nevertheless recognizes to be potentially positive. ${ }^{71}$ For example, coercion may be beneficial in situations involving parental supervision of children and self-defense against an attacker. ${ }^{72}$ Thus, an important additional difficulty im Professor Westen's attempt to distinguish between virtue and vice words, assummg they exist at all, is that this division withm his category is not permanent or stable. Instead, the subcategories of virtue words and vice words simply contain terms that "usually" merit either the virtue or vice label.

This linguistic indeterminacy, however, does not in itself demonstrate that the virtue and vice labels are necessarily indefensible. Rather, the ambiguity of these sets makes any attempt to link them to particular concepts such as "freedom" and "coercion" more problematic.

\section{The InADEQUacies of the Description-Prescription DiсHOTOMY}

One of my criticisms of Professor Westen's virtue-vice category has been my rejection of the idea that the content of terms can be entirely descriptive or entirely normative. Instead, I have argued that these elements conjoin in one degree or another in all terms to generate meaning. Yet at the same time I' believe that some of the most important points Professor Westen makes in Virtue Words and Vice Words have to do with the different senses of "freedom" or "coercion" or "threat" that can be and are generated by the respective descriptive and normative uses of such terms. My ability to hold these two attitudes simultaneously and consistently requires some explication, but my efforts to resolve this diffculty have led me to some basic insights concerning the distinctions between and deficiencies of our respective approaches to language.

\section{A. Definition, Explanation, and Justification: On the Distinction Between Microfacts and Macrofacts.}

Both Professor Westen and I have argued that the analysis involved in legal and moral linguistics is essentially dichotomous or bipolar in character-that is, the meaning of terms can be isolated by examining two basic eleinents. He has labeled those elements description and prescription, while I have labeled them definition and theory, or sometimes description and justification-labels that roughly correspond to a conventional "fact-value" dichotomy. Our analytical categories are differ-

71. Id. at 592 ("[W]e carelessly assume that all coercion is presumptively bad." (footnote omitted)).

72. Id. at $592 \mathrm{n} .146$ ("[C]oercion is not always wrong (quite obviously: one coerces the small child not to run across the highway, or the murderer to drop his weapon) ...." (quoting Held, Coercion and Coercive Offers, in Nomos XIV: COERCION 2 (J. Pennock \& J. Chapman eds. 1972))). 
ent, however, in inore ways than their labels. Indeed, the important substantive distinctions between thein demonstrate that each of us has glossed over an important element of meaning.

The necessity of this additional element, which I will explore only briefly in this section, stems from the recognition that a simple "factvalue" dichotomy fails to account for two distmet sorts of "facts," each generating our descriptive understanding of the world (and particularly here, the linguistic world). For convenience, I will call these two kinds of facts "inicrofacts" and "macrofacts." Microfacts are individual bits of descriptive data; in linguistics, these are single, discrete circuinstances in which a term is used by an individual. Macrofacts, however, are not just aggregate collections of descriptive data, but collections that are structured or organized according to some descriptive theme or principle. In linguistics, the macrofact of conventional usage of a term in society will be the background against which an individual's use of a term can be compared. The descriptive content of a term based on microfacts may be different from that of the sanie term based on macrofacts, and this distinction necessarily affects the linguistic schenies that both Professor Westen and I have employed.

The distinction between microfacts and macrofacts is already reflected in my analytical scheme, but the unique roles of these elements have not yet been sufficiently articulated. My dichotomy of definition and theory, for exaniple, does not in itself embody this distinction. On the one hand, a definitional analysis of a concept is in part microfactual because it is a report of the actual incidents of use of a term, incidents that can then be aggregated to form a set. This report becomes macrofactual only when the set is structured or organized by identifying the standard, recurring elements or characteristics that constitute the concept-in other words, the bits of information that are conveyed when the term is used. "Ownership" is a good example. The set of microfactual instances of use of that term discloses certain inacrofactual features such as the "right to sell," the "right to exclude," and so on.73

By the same token, macrofacts also play a role in my "theory" category. A theoretical exercise is distinct from a definitional one, in my jargon, because a theory emphasizes some deeper foundation for the definitional substance of a concept. But that foundation can be of two different types: justificatory (normative, value-based) or explanatory (macrofactual). A justificatory theory focuses primarily on the moral legitimacy of a concept, and then secondarily and subordinately on the

73. See Honore, Ownership, in OXford Essays IN JURISPRUDENCE 112-28 (A. Guest ed. 1961) (discussing the "standard incidents" of ownership). 
facts of its actual use in legal and moral discourse. These facts are understood and assessed by reference to some normative theme-for example, ownership could be understood to embody a Hegelian personality theory of property. ${ }^{74}$ An explanatory theory, on the other hand, explains how a concept came to acquire its current characteristics. That is, the definition of a term, based on microfactual data and macrofactual general characteristics, is understood more fundamentally by reference to a descriptive, macrofactual theme, rather than by reference to a normative one. For example, ownership could be interpreted as embodying economic efficiency. ${ }^{75}$

Nevertheless, the "full" meaning or substance of a concept is a function of both definition and theory, and of both microfacts and macrofacts. These categories combine to create in essence three exercises at the foundation of linguistic analysis: definition (microfacts and macrofacts), explanation (macrofacts), and justification (normative values).

The microfact-macrofact distimction is also not sufficiently recognized in Professor Westen's description-prescription dichotomy. Althougl he emphasizes a clean break between description and prescription, his descriptive technique places too much emphasis on microfacts, and virtually ignores macrofacts. His sense of a lingnistic "fact" is captured entirely, as I read his article, by the inanner in which a term is used by an individual speaker. Thus, the concept of "threat," as Professor Westen analyzes it, has two levels or "baselines"76 from which its meaning is derived: one is descriptive and anchored in the perception of the individual victim; another is prescriptive, and based upon a nonindividual (societal? biblical?) perspective establishing a set of accepted values from which the interaction between the victim and the individual making the threat is normatively assessed.77 Professor Westen's approach does not include, however, a macrodescriptive perspective that attempts to put the victim's microdescriptive perceptions in a larger factual context. An example of reasoning froin this macrodescriptive perspective would be the following: "From observing a large number of cases we have determined that people feel that if $\mathrm{X}$ occurs, their incomes will drop, and that they therefore refer to $X$ as a threat to their welfare. In fact, however, careful economic analysis demonstrates that the occur-

74. See Terrell, "Property," "Due Process," supra note 8, at 874; Radin, Property and Personhood, 34 STAN. L. REv. 957, $971-78$ (1982).

75. See Terrell, "Property," "Due Process," supra note 8, at 875 \& n.57.

76. Westen defines "baseline" as "a stipulated starting point ... from which to measure ... changes in [an individual's] condition." Westen, supra note 4, at 572. These baselines serve the purpose of "distinguishing threats from offers for purposes of coercion." Id. at 575.

77. Id. at 575-87. 
rence of $\mathrm{X}$ will not produce a decrease in income in the vast majority of cases. Thus, while people generally perceive $\mathrm{X}$ as a threat, in fact it is not."

The macrofact category is of critical importance because language is itself a macrofact, rather than a microfact. The "legitimacy" of a term's use is measured in societal, not individual, terms because communication-the foundational principle of language-is an interactional phenomenon. Thus, in the final analysis "we" inust determine whether a term like "threat" has been used "properly" in a given instance, and that perception of propriety will not be based solely on nornative values. Rather, some reference to the larger factual (historical, cultural) context in which the term is used will be involved.

Microfacts therefore play an important role in linking, as well as distinguishing, descriptive and prescriptive linguistic elements. A good illustration is again Professor Westen's examination of the term "threat." $\mathrm{He}$ concludes that the term has two different meanings, one purely descriptive (froin the point of view of the agent) and the other purely norinative (an aggregated normative assessment). ${ }^{78}$ Although his insight into levels of meaning here is an important one, I do not believe he portrays the situation accurately. The two levels of ineaning Professor Westen attributes to threat can only be "purely descriptive" or "purely normative" with very odd, and I think maccurate, understandings of these supposed categories. His "purely descriptive" category achieves this status solely because he limits it to one individual-the victim-and assumes that the "fact" of this person's attitude must be a normatively neutral event. Although I agree that our perception of this attitude can be reduced to a mere anecdotal fact like an entry in an opinion poll, the process by which that victim arrived at his perception of loss could well have involved (indeed, I would argue inust have involved) some assessinent of the normative "goodness" and "badness" of the range of options within his circumstances. This individual's conclusion-"I feel threatened"- may have involved a purely selfish sense of individual aggrandizement that rejects current moral attitudes about respect for others. But in all likelihood, the victin's mental exercise was not so myopic. The victim's very use of the term "threat" calls into play its meanmg as part of society's language (a inacrofact), not his own private language (a nonexistent microfact). Society's words then unavoidably carry with them a coinplex of generative normative baggage as well. Hence, a nornative component to the term, no inatter how small or inconsequential, will be involved in the victim's use of the term. The use of

78. Id. 
the term may "primarily" convey normatively neutral, descriptive "facts" as Professor Westen understands and uses that idea, but it could not have been completely devoid of normative substance.

The same is true about the supposed "prescriptive only" level of meaning to which Professor Westen refers. Again, meaningful, contextual communication is impossible unless the language used possesses some underlying definitional (descriptive) content, both microfactual and macrofactual, even if this descriptive content is heavily and purposefully value-laden. This is precisely the conclusion Professor Westen has apparently reached with regard to the concept of "equahty." Having earlier insisted that the substance of equality was entirely normative, ${ }^{79}$ he now acknowledges that a key communicative role is played by the underlying macrofactual definitional structure of the concept. ${ }^{80}$ The necessity for some descriptive content also applies to the term "threat," even when used in the normative inode characterized by Professor Westen. That is, for any normative substance to be attached to a term, some minimal, agreed-upon definitional (inacrodescriptive) frainework for the term must be present. This is not to say that the descriptive aspect of the term will be its dominant feature; quite the contrary, the normative sense of the term may be the dominant, controlling variable in the complex function that generates ineaning.

\section{B. Objectivity, Subjectivity, and Rhetorical Force.}

The complication introduced by the idea of a inacrofact can be stated in an alternative, more abstract form that suggests an explanation for the problematic notion that some words have relatively greater rhetorical force than others. In a recent article ${ }^{81}$ Stephen Massey examined the consequences of the fact-value dichotoiny as it relates to the troublesome philosophical concept of "self-respect." In doing so, he cliallenged from a new perspective the adequacy of the descriptive-prescriptive dichotomy at the heart of Professor Westen's analytic technique.

Professor Massey observed that "self-respect" could be understood in either of two ways: as a descriptive, individual fact or as a normative moral value. ${ }^{82}$ If it is the former, then it is entirely subjective and cannot generate sweeping inoral conclusions. ${ }^{83}$ If it is the latter, tlien an "objec-

79. See supra note 12 and accompanying text.

80. Westen, supra note 4, at 543-44 (identifying the core definitional element of equality as "the concept that likes should be treated alike").

81. Massey, Is Self-Respect a Moral or a Psychological Concept?, 93 ETHIcs 246 (1983).

82. Id. at 248-55.

83. Id. at 258 ("The subjective concept of self-respect is independent of all moral notions (..."). 
tive" assessment of self-respect might be possible by referring to an agreed-upon standard that prescribes a "right kind" of self-respect. ${ }^{84}$ But this standard necessarily presupposes and fixes the normative substance of self-respect, making the use of the term self-respect a conclusion rather than a part of a philosophical analysis. Consequently, the focus in any such analysis must be the normative principles underlying and constituting the concept of self-respect, not the fact of self-respect itself. 85

Professor Massey's observations may seem to track Professor Westen's examination of "freedom," "coercion," "threat," and so on, but Professor Massey imtroduces critical additional elements and perspectives. Professor Massey's analysis indicates that the distinctions among various meanings of a term cannot be understood simply by segregating their descriptive and prescriptive content. Instead, the subjectivity of the descriptive exercise must be distinguished from the comparative objectivity of the prescriptive exercise. This is a difficult proposition to grasp because we usually ascribe objectivity to the descriptive, "fact" category of analysis, and subjectivity to the prescriptive, "value" category. Professor Massey correctly notes, however, that from the point of view of the audience assessing the use of a particular concept in discourse, the objective-subjective labels are paradoxically reversed. The idea of an "audience" reverses the usual objective-subjective labels because it embodies the notion of a macrofact. Hence, Professor Massey notes the subjectivity of individual, psychological, "descriptive" references to self-respectthe microfacts of my earlier discussion - and the comparative objectivity of the conventional (audience-based) normativity of the concept-in

84. Id. at 253 ("According to the objective account, it is necesary but not sufficient for selfrespect that a person believe he acts in ways that are worthy. In addition, the person must have the correct views about his worth, and act in ways that are objectively worthy.").

The subjective/objective dichotomy has been the object of a staggering amount of literature, much of it continental, some of it at the heart of the Critical Legal Studies movement, and nearly all of it outside the scope of these brief comments. See, e.g., R. BERNSTEIN, BEYOND OBJECTIVISM and Relativism: Science, Hermeneutics, and Praxis (1983); Unger, The Critical Legal Studies Movement, 96 HARV. L. REv. 563, 567-76 (1983).

85. In other words, the psychological, "descriptive" references to self-respect refer only to the psychological fact of self-respect that relies on individual, subjective valuations. The normative endorsement or condemnation of a particular person's self-respect involves something more. Such judgment carries with it a tacit endorsement or condemnation of that person's conception of "right" behavior as well-whether that person has the "right kind" of self-respeet. In such cases, reference must be made to some antecedent standard; a person's self-respect cannot be viewed as morally appropriate simply because that person so views it. The standard to be applied is "objective" in the sense that it involves not individual valuations, but some larger, socially-endorsed patterns of attitude and behavior. 
other words, a form of macrofact. ${ }^{86}$

We therefore have a new tension about which we must be sensitive in the context of communication. On the one hand, we have microfactual uses of a term where the descriptive content is subjectively supphied. On the other hand, we have macrofactual, value-laden uses of the same term where the descriptive content is objectively supplied and derived from values that can be identified but cannot be "proved," and hence reinain controversial. ${ }^{87}$

This complex phenonienon may in turn help to explain why Professor Westen's attachunent of "great rhetorical force" to his virtue and vice words remains so troublesome. Perhaps sonve sense of "rhetorical usefulness" (rather than "force") could be based on the subtle separation of descriptively subjective and prescriptively objective content of a term. The descriptively subjective content of a term makes the term an individual "fact," but insulates and constrains analysis due to the inherent difficulty of interpersonal comparisons ainong different aggregations of fact. The prescriptively objective content of a term makes the term a social "value," the conventional normative substance of which might be "discovered" with diligent study, but which would remain inescapably controversial. Thus, ambiguity and flexibility, both descriptively and normatively, are deeply embedded linguistic characteristics that allow many terms, not just virtue words and vice words, to "speak around" the substance of the controversy to which they are seemingly addressed.

\section{CONCLUSION}

Much work must yet be done to develop adequately the relationships among language, reasoning, and rhetoric. Professor Westen las contributed significantly to our understandimg of the nature and importance of conceptual categories in legal and moral contexts, and he will no doubt continue to do so. I have sought here, however, to identify certain major tensions and difficulties that $I$ believe burden his analytic technique. I ain troubled by the separation he emphasizes between descriptive and prescriptive meanings of terms, and by the virtue-vice category of terms that is, in part, a function of that separation. In contrast, I have emphasized a more complex fact-value dichotoniy at the foundation of linguistic substance. I do not pretend, however, that in these few pages I liave established a complete foundation for the distinction between

86. Compare Massey, supra note 81 , at 249 (listing the criteria of self-respect from a subjective point of view) with id. at 254-55 (noting that an objective account of self-respect must make reference to moral values).

87. Id. at $255-61$. 
microfacts and macrofacts, or that I have discussed the full range of their miplications.

Despite our analytic differences, Professor Westen and I share a fundamental concern with the nature and structure of legal questions and argumentation. We both believe that communication and legitimacy are inextricably bound, making attention to language unavoidable for legal and moral theory. These comments on and criticisms of Professor Westen's article are therefore intended both to underscore the importance of conceptual analysis and to add to the debate about it. 